
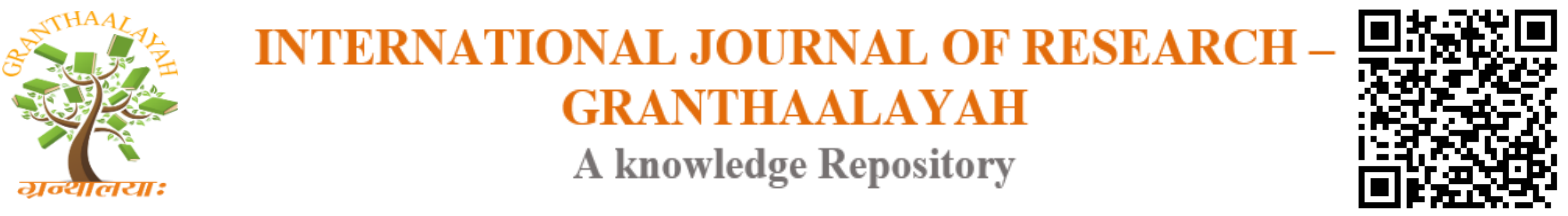

Social

\title{
EFFECTS OF EXPLOSIVE STRENGTH AND STRENGTH ENDURANCE BASED CIRCUIT TRAINING ON SPEED PERFORMANCE
}

\author{
Dr.D.Maniazhagu ${ }^{1}$, Mr. Kannadasan ${ }^{2}$, Ms.S.Malar ${ }^{3}$ \\ ${ }^{1}$ Assistant Professor, Department of Physical Education and Health Sciences, Alagappa \\ University, Tamilnadu, India \\ ${ }^{2}$ M.Phil Scholar, Department of Physical Education and Health Sciences, Alagappa University, \\ Tamilnadu, India \\ ${ }^{3}$ PhD Scholar, Department of Physical Education and Health Sciences, Alagappa University, \\ Tamilnadu, India
}

\begin{abstract}
The purpose of the study was to find out the effects of explosive strength and strength endurance based circuit training on speed performance. To achieve the purpose of the study, thirty boys' student in the age group 13 to 14 were selected as subjects at random. The selected subjects were from RCM High School, Natarajapuram, Sivagangai(DT), Tamilnadu. The study was formulated as pre and post-test random group design, in which thirty students were divided into three equal groups. The experimental group-1 $(\mathrm{n}=10$, ESbCT) underwent explosive strength based circuit training, the experimental group-2 $(n=10$, SEbCT) underwent strength endurance based circuit training and group 3 served as control group $(n=10, C G)$ did not undergo any specific training. In this study, two training programme were adopted as independent variables, i.e., explosive strength based circuit training and strength endurance based circuit training. The speed was selected as dependent variables. The speed was tested by 50 meters run recoded in seconds. The selected two treatment group namely explosive strength based circuit training and strength endurance based circuit training were performed five days in week for the period of six weeks, as per the stipulated training programme. The speed performance was collected before and after the training period. The collected pre and post test data was critically analyzed with apt statistical tool of one way analysis of co variance, for observed the significant adjusted post-test mean difference of three groups. The Scheffe's post hoc test was used to find out pair-wise comparisons between groups. To test the hypothesis 0.05 level of significant was fixed in this study. The nature of speed highly improved in explosive strength based circuit training than the strength endurance based circuit training.
\end{abstract}

Keywords: Explosive Strength Based Circuit Training (ESbCT); Strength Endurance Based Circuit Training (SEbCT); Speed. 
Cite This Article: Dr.D.Maniazhagu, Mr. Kannadasan, and Ms.S.Malar. (2017). "EFFECTS OF EXPLOSIVE STRENGTH AND STRENGTH ENDURANCE BASED CIRCUIT TRAINING ON SPEED PERFORMANCE." International Journal of Research - Granthaalayah, 5(8:SE), 76-82. https://doi.org/10.29121/granthaalayah.v5.i8(SE).2017.2251.

\section{Introduction}

Circuit training was first proposed by Morgan and Adamson (1959) of Leeds University as a method for developing general fitness. Their initial circuit training routine considered of several stations arranged in a circle (hence the name circuit training) so as to work muscle groups alternately from station to station. As circuit training grew in popularity, other authors began to provide additional information. Perhaps the best book on the market is Circuit Training for All sports (Scholich, 1992).

\section{Methodology}

The selected two treatment groups namely explosive strength based circuit training and strength endurance based circuit training were performed five days in a week for the period of six weeks, as per the stipulated training program.

Training approaches for experimental group - I (ES $\left.\mathrm{B}_{\mathrm{B}} \mathrm{CT}\right) 1$ to 2 weeks

\begin{tabular}{|c|c|c|c|c|}
\hline Days & Exercise & Duration & Sets & $\begin{array}{c}\text { Rec.In } \\
\text { between sets }\end{array}$ \\
\hline Monday to Friday & $\begin{array}{l}\text { Half squats } \\
\text { Push-ups } \\
\text { Bent-knee sit ups } \\
\text { Two legged low hops on the spot } \\
\text { Back extensions } \\
\text { Pull ups } \\
\text { Burpees } \\
\text { Shuttle run }\end{array}$ & $\begin{array}{l}\text { Each exercise } \\
20 \text { seconds }\end{array}$ & three & Three minutes \\
\hline $\begin{array}{l}\text { Repetitions } \\
\text { Rest } \\
\text { Stations/Circuit } \\
\text { Time/ circuit } \\
\text { Circuits/Session } \\
\text { Time/ Session } \\
\text { Frequency } \\
\text { Load of the week } \\
\text { Recovery in between }\end{array}$ & $\begin{aligned} & : \text { as many as possible in } 20 \mathrm{se} \\
& : 30 \text { Seconds } \\
& : 8 \text { exercise station-clock wis } \\
& : 2 \text { minutes and } 40 \text { seconds } \\
& : 3 \\
& : 8 \text { minutes } \\
& : 5 \text { days/week } \\
& : 24 \text { minutes } \\
\text { circuits } & : 3 \text { minutes }\end{aligned}$ & e order & & \\
\hline \multicolumn{5}{|c|}{ Explosive strength based circuit training $\left(\mathrm{ES}_{\mathrm{b}} \mathrm{CT}\right) 3$ to 4 weeks } \\
\hline Days & Exercise & Duration & Sets & $\begin{array}{c}\text { Rec.In } \\
\text { between sets }\end{array}$ \\
\hline Monday to Friday & $\begin{array}{l}\text { Half squats } \\
\text { Push-ups } \\
\text { Bent-knee sit ups }\end{array}$ & $\begin{array}{l}\text { Each exercise } \\
30 \text { seconds }\end{array}$ & three & Three minutes \\
\hline
\end{tabular}




\begin{tabular}{|l|l|l|l|l|}
\hline & Two legged low hops on the spot & & & \\
Back extensions & & & \\
Pull ups & & & \\
& Burpees & & & \\
\hline
\end{tabular}

\section{Repetitions}

Rest

Stations/Circuit

Time/ circuit

Circuits/Session

Time/ Session

Frequency

Load of the week

Recovery in between circuits
: As many as possible in 30 seconds

: 30 Seconds

: 8 exercise station-clock wise order

$: 4$ minutes

$: 3$

: 12 minutes

: 5 days/week

: 36 minutes

Explosive strength based circuit training $\left(\mathrm{ES}_{\mathrm{b}} \mathrm{CT}\right) 5$ to 6 weeks

\begin{tabular}{|c|c|c|c|c|}
\hline Days & Exercise & Duration & Sets & $\begin{array}{l}\text { Rec.In } \\
\text { between sets }\end{array}$ \\
\hline Monday to Friday & $\begin{array}{l}\text { Half squats } \\
\text { Push-ups } \\
\text { Bent-knee sit ups } \\
\text { Two legged low hops on the spot } \\
\text { Back extensions } \\
\text { Pull ups } \\
\text { Burpees } \\
\text { Shuttle run }\end{array}$ & $\begin{array}{l}\text { Each exercise } \\
40 \text { seconds }\end{array}$ & three & Three minutes \\
\hline $\begin{array}{l}\text { Repetitions } \\
\text { Rest } \\
\text { Stations/Circuit } \\
\text { Time/ circuit } \\
\text { Circuits/Session } \\
\text { Time/ Session } \\
\text { Frequency } \\
\text { Load of the week } \\
\text { Recovery in betwee }\end{array}$ & $\begin{array}{l}: \text { As many as possible in } 30 \text { second } \\
: 30 \text { Seconds } \\
: 8 \text { exercise station-clock wise orde } \\
: 5 \text { minutes } 20 \text { seconds } \\
: 3 \\
: 16 \text { minutes } \\
: 5 \text { days/week } \\
: 48 \text { minutes } \\
\text { circuits: } 3 \text { minutes }\end{array}$ & & & \\
\hline \multicolumn{5}{|c|}{ TRAINING APPROACHES FOR EXPERIMENTAL GROUP - II } \\
\hline Days & Exercise & Duration & Sets & $\begin{array}{c}\text { Rec.In } \\
\text { between sets }\end{array}$ \\
\hline Monday to Friday & $\begin{array}{l}\text { Half squats } \\
\text { Push-ups } \\
\text { Bent-knee sit ups } \\
\text { Two legged low hops on the spot } \\
\text { Back extensions } \\
\text { Pull ups } \\
\text { Burpees }\end{array}$ & $\begin{array}{l}\text { Each exercise } \\
20 \text { seconds }\end{array}$ & Three & Three minutes \\
\hline
\end{tabular}




\begin{tabular}{l|l|l|}
\hline & Shuttle run & \\
\hline Repetitions & $:$ as many as possible in 20 seconds \\
Rest & $: 30$ Seconds \\
Stations/Circuit & $: 8$ exercise station-clock wise order \\
Time/ circuit & $: 2$ minutes and 40 seconds \\
Circuits/Session & $: 3$ \\
Time/ Session & $: 8$ minutes \\
Frequency & $: 5$ days/week \\
Load of the week & $: 24$ minutes
\end{tabular}

Strength Endurance based circuit training $\left(\mathrm{SE}_{\mathrm{b}} \mathrm{CT}\right) 3$ to 4 weeks

\begin{tabular}{|l|l|l|l|l|}
\hline \multicolumn{1}{|c|}{ Days } & \multicolumn{1}{|c|}{ Exercise } & \multicolumn{1}{|c|}{ Duration } & Sets & \multicolumn{1}{c|}{$\begin{array}{c}\text { Rec.In } \\
\text { between sets }\end{array}$} \\
\hline & $\begin{array}{l}\text { Half squats } \\
\text { Push-ups } \\
\text { Bent-knee sit ups } \\
\text { Two legged low hops on the spot }\end{array}$ & $\begin{array}{l}\text { Each exercise } \\
\text { Monday to Friday }\end{array}$ & Three & Three minutes \\
& $\begin{array}{l}\text { Back extensions } \\
\text { Pull ups } \\
\text { Burpees } \\
\text { Shuttle run }\end{array}$ & & \\
\hline
\end{tabular}

$\begin{array}{ll}\text { Repetitions } & : \text { As many as possible in } 30 \text { seconds } \\ \text { Rest } & : 30 \text { Seconds } \\ \text { Stations/Circuit } & : 8 \text { exercise station-clock wise order } \\ \text { Time/ circuit } & : 4 \text { minutes } \\ \text { Circuits/Session } & : 3 \\ \text { Time/ Session } & : 12 \text { minutes } \\ \text { Frequency } & : 5 \text { days/week } \\ \text { Load of the week } & : 36 \text { minutes }\end{array}$

Strength Endurance based circuit training $\left(\mathrm{SE}_{\mathrm{b}} \mathrm{CT}\right) 5$ to 6 weeks

\begin{tabular}{|c|c|c|c|c|}
\hline Days & Exercise & Duration & Sets & $\begin{array}{c}\text { Rec.In } \\
\text { between sets }\end{array}$ \\
\hline Monday to Friday & $\begin{array}{l}\text { Half squats } \\
\text { Push-ups } \\
\text { Bent-knee sit ups } \\
\text { Two legged low hops on the spot } \\
\text { Back extensions } \\
\text { Pull ups } \\
\text { Burpees } \\
\text { Shuttle run }\end{array}$ & $\begin{array}{l}\text { Each exercise } \\
40 \text { seconds }\end{array}$ & Three & Three minutes \\
\hline \multicolumn{5}{|c|}{ Repetitions $\quad:$ As many as possible in 30 seconds } \\
\hline Rest & \multicolumn{4}{|c|}{$: 30$ Seconds } \\
\hline Stations/Circuit & \multicolumn{4}{|c|}{ : 8 exercise station-clock wise order } \\
\hline Time/ circuit & \multicolumn{4}{|c|}{ : 5 minutes 20 seconds } \\
\hline Circuits/Session & \multicolumn{4}{|l|}{$: 3$} \\
\hline Time/ Session & \multicolumn{4}{|l|}{16 minutes } \\
\hline Frequency & \multicolumn{4}{|l|}{ : 5 days/week } \\
\hline Load of the week & \multicolumn{4}{|l|}{ : 48 minutes } \\
\hline
\end{tabular}


Table 1: The Results of Analysis of Covariance on Speed of Different Groups (Scores in Seconds)

\begin{tabular}{|c|c|c|c|c|c|c|c|c|c|}
\hline \multicolumn{2}{|c|}{ Test Conditions } & $\begin{array}{l}\text { Group 1 } \\
\text { ES }_{b} \mathbf{C T}\end{array}$ & $\begin{array}{l}\text { Group 2 } \\
\mathrm{SE}_{\mathrm{b}} \mathrm{CT}\end{array}$ & $\begin{array}{l}\text { Group } 3 \\
\text { CG }\end{array}$ & SV & SS & Df & MS & $\begin{array}{l}\text { 'F' } \\
\text { Ratio }\end{array}$ \\
\hline \multirow{2}{*}{ Pre test } & Mean & 9.31 & 9.29 & 9.28 & B & 0.005 & 2 & 0.002 & \multirow{2}{*}{0.22} \\
\hline & S.D. & 0.09 & 0.08 & 0.09 & $\mathrm{~W}$ & 0.234 & 27 & 0.009 & \\
\hline \multirow{2}{*}{ Post test } & Mean & 8.90 & 9.06 & 9.26 & B & 0.651 & 2 & 0.326 & \multirow{2}{*}{$65.20^{*}$} \\
\hline & S.D. & 0.08 & 0.07 & 0.07 & W & 0.148 & 27 & 0.005 & \\
\hline $\begin{array}{l}\text { Adjusted } \\
\text { post test }\end{array}$ & Mean & 8.89 & 9.06 & 9.27 & $\begin{array}{l}\mathrm{B} \\
\mathrm{W}\end{array}$ & $\begin{array}{l}0.707 \\
0.054\end{array}$ & $\begin{array}{l}2 \\
26\end{array}$ & $\begin{array}{l}0.353 \\
0.002\end{array}$ & $176.50^{*}$ \\
\hline
\end{tabular}

* Significant at .05 level of confidence. The required table value for test the significance was 3.35 , and 3.37, with the df of 2 and 27,2 and 26 respectively.

\section{Results on Speed}

The pre test mean and standard deviation on speed scores G1, G2, and G3 were 9.31 $\pm 0.09,9.29 \pm$ 0.08 and $9.28 \pm 0.09$ respectively. The obtained pre test $F$ value of 0.22 was lesser than the required table $F$ value 3.35 . Hence the pre test means value of explosive strength, strength endurance based circuit training and control group on speed before start of the respective treatments were found to be insignificant at 0.05 level of confidence for the degrees of freedom 2 and 27. Thus this analysis confirmed that the random assignment of subjects into three groups were successful. The post test mean and standard deviation on speed of G1, G2 and G3 were $8.90 \pm 0.08,9.06 \pm 0.07$ and $9.26 \pm 0.07$ respectively. The obtained post test $F$ value of 65.20 was higher than the required table $\mathrm{F}$ value of 3.35. Hence the post test means value of explosive strength based circuit training and strength endurance based circuit training on speed were found to be significant at 0.05 level of confidence for the degrees of freedom 2 and 27. The results proved that the selected two training interventions namely explosive strength and strength endurance based circuit training were produced significant improve better than the control group of the sample populations. The adjusted post test means on speed scores of G1, G2 and G3 were $8.89,9.06$ and 9.27 respectively. The obtained adjusted post test $\mathrm{F}$ value of $176.50^{*}$ was higher than the required table $\mathrm{F}$ value of 3.37. Hence the adjusted post test means value of explosive strength based circuit training and strength endurance based circuit training on speed were found to be significant at 0.05 level of confidence for the degrees of freedom 2 and 26. The results confirm that the selected two training interventions namely explosive strength and strength endurance based circuit training on speed were produced significant difference among the groups. In order to find out the superiority effects among the treatment and control groups the Seheffe's post hoc test were administered. The outcomes of the same are presented in the table 2 .

Table 2: The results of scheffe's post hoc test mean differences on SPEED among THREE groups (Scores in seconds)

\begin{tabular}{|l|l|l|l|l|}
\hline $\begin{array}{l}\text { Group 1 } \\
\mathbf{E S}_{\mathbf{b}} \mathbf{C T}\end{array}$ & $\begin{array}{l}\text { Group 2 } \\
\mathbf{S E}_{\mathbf{b}} \mathbf{C T}\end{array}$ & $\begin{array}{l}\text { Group 3 } \\
\mathbf{C ~ G}\end{array}$ & $\begin{array}{l}\text { Mean } \\
\text { Differences }\end{array}$ & $\begin{array}{l}\text { Confidence } \\
\text { Interval Value }\end{array}$ \\
\hline 8.89 & 9.06 & & $0.17^{*}$ & 0.01 \\
\hline 8.89 & & 9.27 & $0.38^{*}$ & 0.01 \\
\hline & 9.06 & 9.27 & $0.21^{*}$ & 0.01 \\
\hline
\end{tabular}

* Significant at .05 level of confidence. 
Table 2 shows the paired mean differences of explosive strength based circuit training, strength endurance based circuit training and control group on speed. The paired wise comparisons results as follows. First comparison: Group 1 and Group 2: The pair wise mean difference of group 1 and group 2 values 0.17 was higher than the confidential interval value of 0.01 . Hence the first comparison was significant. The results of this comparison clearly proved that both training have produced significantly different improvements on speed. Second comparison: Group 1 and Group 3: The pair wise mean difference of group 1 and group 3 values 0.38 was higher than the confidential interval value of 0.01 . Hence the second comparison was significant. The results of this comparison clearly proved that explosive strength based circuit raining have produced greater improvements on speed than the control group. Third comparison: Group 2 and Group 3: The pair wise mean difference of group 2 and group 3 values 0.21 was higher than the confidential interval value of 0.01 . Hence the third comparison was significant. The results of this comparison clearly proved that strength endurance based circuit training have produced greater improvements on speed than the control group.

\section{Discussion on Speed}

After analyzing the statistical end results the researcher found that the selected training groups have significantly improved the quality of speed from the base line to post interventions. The pre to post intervention was present as follows. The explosive strength based circuit training group from pre $(9.31 \pm 0.09)$, to post $(8.90 \pm 0.08)$ and strength endurance based circuit training group from pre $(9.29 \pm 0.08)$ to post $(9.06 \pm 0.07)$ have significantly changed the pre to post results. The present study demonstrates an increase in speed performance of $0.004 \%$ and $0.002 \%$ for explosive strength and strength endurance based circuit training groups respectively. The results of Venkatachalapathy $\mathbf{R}$ (2015) conducted a study on effect of circuit training programme on speed and agility. His study revealed that was found that there was a significant improvement on speed and agility for circuit training group when compared with the control group. The research findings of Ramesh Kannan, S Dr. B. Chittibabu, Dr. P.C. Tripathy, M.D. (2015) effect of intensive sports specific endurance circuit training on selected motor fitness components of male handball players during preparatory phase. They concluded that intensive sports specific endurance circuit training for 12 weeks is effective enough in maintaining motor fitness components like speed and power of handball players. The research findings of Sudhakar Babu1.M, P. P. S. Paul Kumar (2013) conducted a study on the effect of selected circuit training exercises on sprinters of high school girls. They concluded that there was significant effect on speed, through selected circuit training exercises.

\section{Conclusion}

The results of this study indicate the nature of speed highly improved in explosive strength based circuit training than the strength endurance based circuit training.

The strength endurance based circuit training also produces better improvement on speed than the control group. The control group did not show any significant changes on speed

\section{References}

[1] APA (6th ed.) Scholich, M., \& Klavora, P. (1992). Circuit training for all sports: Methodology of effective fitness training. Toronto: Sport Books Publisher. 
[2] Dr. R. Venkatachalapathy, (2015), Effect of Circuit Training Programme on Speed and Agility, Received 6th January 2015, Accepted 20th February 2015. Retrieved on 27.04.2016

[3] Golden, S. A. R. (2017). Recent Research in Social Sciences \& Humanities. EduPedia Publications (P) Ltd.

[4] M. Sudhakar Babu1, P. P. S. Paul Kumar(2013), The Effect of Selected Circuit Training Exercises on Sprinters of High School Girls, International Journal of Science and Research (IJSR) ISSN (Online): 2319-7064 Volume 2 Issue 11, November 2013, Retrieved on 28.04.2016

[5] S. RameshKannan, Dr. B. Chittibabu, Dr. P.C. Tripathy, M.D.(2015), effect of intensive sports specific endurance circuit training on selected motor fitness components of male handball players during preparatory phase, Asian Journal of Applied Research (AJAR) 2015, Retrieved on 28.04.2016 